\title{
Determinants of Successful Labour Market Reintegration for Highly Educated Return Migrants in Slovakia ${ }^{1}$
}

\author{
Lucia Mýtna Kureková ${ }^{2}$ - Zuzana Žilinčíková ${ }^{3}$ \\ Centre for Social and Psychological Sciences, Institute for Forecasting, SAV, \\ Bratislava \\ Centre for Demographic Research (DEMO), Institute for the Analysis of Chan- \\ ge in Contemporary and Historical Societies, Université Catholique de Lou- \\ vain, Louvain-la-Neuve
}

\begin{abstract}
Determinants of Successful Labour Market Reintegration for Highly Educated Return
Migrants in Slovakia. This paper examines factors contributing to the successful labour market reintegration of return migrants to Slovakia in 2015. We use data from a web survey to study the relative importance of migration and return motivations, labour market factors and personal characteristics in explaining the success or failure of post-return labour market integration. We find that migration purpose and the preparedness of returnees affect reintegration prospects more than labour market factors. Those migrants who returned after having fulfilled goals defined at the outset of migration had significantly higher chances of reintegrating successfully. Returnees' expectations in terms of employment opportunities and wage levels might hamper employment prospects after return. Our work calls for further research to better understand the interrelated nature of migration motivations, return motivations and post-return labour market outcomes.

Sociológia 2020, Vol. 52 (No. 6: 624-647)

https://doi.org/10.31577/sociologia.2020.52.6.26
\end{abstract}

Key words: Return migration; labour market; reintegration; web survey; Slovakia

\section{Introduction}

The accession of Central and Eastern European countries (CEE) to the European Union was followed by massive outflows of young people to Western European countries (Kahanec - Zimmermann 2010). The key findings describing the East-West migration highlight the positive selection of migrants based on age and education, and high employment rates of CEE migrants in the West, but in low-skilled and low-paid jobs, accompanied by relatively weak upward occupational mobility (Drinkwater et al. 2009; Kahanec - Zimmermann 2010; Voitchovsky 2014; Kahanec - Fabo 2013). With the onset of the 2008/2009 economic crisis, the initial expectations were that many CEE migrants would return home due to worsened labour market conditions in several key destination countries (Kahanec - Zimmermann 2016). However, studies to date have

\footnotetext{
1 This work was supported by the European Union's Seventh Framework Programme for research, technological development and demonstration, Grant number: 613256; and by VEGA grant no. 2/0002/18.

2 Address: Lucia Mýtna Kureková, PhD., Centre for Social and Psychological Sciences, Institute for Forecasting, Slovak Academy of Sciences, Šancová 56, 81105 Bratislava, Slovak Republic. E-mail: lucia.mytna-kurekova@savba.sk

3 Address: Zuzana Žilinčíková, PhD., Centre for Demographic Research (DEMO), Institute for the Analysis of Change in Contemporary and Historical Societies, Université Catholique de Louvain, Place Montesquieu 1, 1348 Louvain-la-Neuve, Belgium. E-mail: zuzana.zilincikova@uclouvain.be
} 
documented that the magnitude of return was rather modest (Barcevičius et al. 2012; Galgóczi et al. 2012; Janicka - Kaczmarczyk 2016), and has varied across the CEE region (Zaiceva - Zimmermann 2016). A new wave of returning has taken place in light of repatriations and returns linked to the Covid-19 world pandemic (Crețan - Light 2020; Šantić - Antić 2020).

While the topic of East-West migration has attracted much scholarly attention (Galgóczi et al. 2013; Holland et al. 2011; Kahanec - Pytliková 2017; Kahanec - Zimmermann 2010), the issue of return migration has to date received comparatively less research focus. In the context of brain drain research, several studies focused on analysing the selectivity of return migration and the labour market performance of returnees (Ambrosini et al. 2011; Martin - Radu 2012; Pungas et al. 2012). Some studies have investigated motivations for return (Barcevičius et al. 2012) or have analysed factors influencing the return likelihood of students studying abroad (Bahna 2018). However, there is relatively less knowledge about factors contributing to the successful return and reintegration of young returnees into the home labour market. This is both academically interesting and policy-relevant, as it can guide interventions to facilitate smooth returns and enhance the personal, familial and societal benefits of intra-EU mobility.

The labour market performance after returning may display specific patterns shaped by the initial determinants of migration and motivations to migrate, macro-economic performance in the host and home countries, as well as various policies, including social and labour market policy. Measuring factors of successful return is therefore a complex task, typically hindered by the availability of suitable data. This paper addresses some of the existing gaps; it uses web-survey data about returnees to Slovakia, collected in 2015, to map what motivated their return, and to analyse factors contributing to successful labour market reintegration. A focus on Slovakia provides an interesting empirical context, combining relatively high levels of return (Zaiceva - Zimmermann 2016) and an unequally performing labour market, with high regional disparities that have originally contributed to relatively high emigration rates (Kahanec-Kureková 2016).

In this paper, we focus on understanding how migration intentions, return motivations and conditions of return affect post-return experiences in terms of labour market reintegration. Specifically, the main objective of our paper is to understand the relative importance of economic and labour market factors, motivations for migration and return, and personal characteristics in explaining differences in migrants' employment outcomes six months after returning to Slovakia. Our collection of data from a web survey helps us to map the return process, as well as the initial migration decision, in an interrelated way that is often not possible with representative datasets that enable studying either mi- 
gration or return. This deepens our understanding of the complexity of factors affecting migration and return processes in the European Union at the microlevel. Due to limitations of our data and the size of the sample, our work should be seen as exploratory, and as establishing a basis for a further research agenda.

\section{Literature review}

The process of return migration and its sustainability has been analysed from two broad perspectives: (a) determinants of the intentions of return, and (b) post-return experiences (Vlase 2013). We adopt a similar approach and review the existing literature from these two perspectives, in order to highlight that the factors determining the return decision and post-return experiences are complex and interrelated.

\section{Reasons for return migration}

Scholars theorize two principal reasons for return migration: it may represent an initial residential location plan during the life course, where for some migrants utility is maximized by incorporating a return; or it may result from mistakes in the initial migration decision, suggesting failed migration (Rooth Saarela 2007). While the first perspective is given support by the new economics of migration theory, the latter is grounded in the neoclassical theory of migration (De Haas et al. 2015), implying that return migration tends to be theorized using broader migration theories (Vlase 2013).

Similarly to migration literature that considers economic factors as the key determinants of emigration, many studies focusing on return decision highlight the primary role of economic factors, such as macro-economic conditions in the home and host country, performance of labour market, or individual-level labour market status (Dustmann 2003; Lindstrom 1996). Dumont and Spielvogel (2008) argue that the different macroeconomic context in the home country and in the host country is a major determinant of the decision to return. This assumption motivated researchers to study an association between return migration patterns in response to the 2008/2009 economic crisis (Kahanec Zimmermann 2016; Galgóczi et al. 2012; Masso et al. 2018).

Research focusing on the CEE region has also looked specifically at the influence of over-education in host countries' labour markets on return decisions or reintegration patterns. On an individual level, a mismatch between skills and jobs abroad, which has been severe for CEE migrants in the West (Voitchovsky 2014), has been identified as a key determinant of the return of Estonian migrants working in Finland (Pungas et al. 2012), but also more generally (Masso et al. 2018). Similarly, Currie (2007) found that Polish returnees commonly frame their decision to return to Poland within the context of frustration with limited labour market progress in the UK. 
Some studies have gone beyond the economic perspective and question the dominant role of economic factors, or consider a broader set of motivations for returning, including familial, social, political and emotional reasons (Barcevičius et al. 2012). Along these lines, Lang et al. (2012) found that return migration to CEE countries has been guided more by private and social motives than by economic reasons. Gherghina and Plopeanu (2020) investigated the importance of emotional relationship to the home country, and found that the intensity of Romanian migrants' ties to the homeland significantly influence their decision to return. The link between family considerations and return does not need to be causal, but rather contextual (Barcevičius et al. 2012).

Another strand of literature focuses on soft factors, such as motivations for migration and return, and the degree of preparedness. In particular, Cassarino (2004) developed a typology of return migrants which goes beyond the success-failure dichotomy and characterizes return migrants by their level of preparedness. In their study of the intentions of Moroccan migrants, De Haas et al. (2015) found that return can be a result of success rather than failure, and that successful economic integration in the host country might even be a precondition for returning. Similarly, Barcevičius et al. (2012) confirmed that returnees' preparedness was of central importance in their reintegration, according to findings for Hungary, Latvia, Poland and Romania.

Post-return experiences: successful reintegration in labour market

The success of the return process may vary depending on the individual characteristics of the migrant, whereby the selection of returnees is likely to affect reintegration trajectories. The majority of studies about returnees in the CEE context document that returnees are positively selected in terms of education (Hazans - Philips 2010; Martin - Radu 2012; Schroth 2013; Smoliner et al. 2012; Zaiceva - Zimmermann 2016). Thus, educational achievement is likely to increase their chances of successful integration upon return.

Regarding the labour market outcomes of returnees, results are mixed. Provided that returnees find employment, they seem to reap benefits in terms of wage premiums. More specifically, Iara (2006) shows that young and male migrants from the CEE countries earn an average wage premium of $30 \%$ if they had worked in Western Europe, but finds no wage premiums for working in other CEE countries. Co et al. (2000) find that for Hungarian returnees, migration experience brings wage premiums only to women and not men. On the other hand, several studies document that returnees face a higher probability of unemployment or inactivity (Masso et al. 2018; Smoliner et al. 2012), but better-educated returnees and older returnees are less likely to be unemployed one year after return (Martin - Radu 2012). Martin and Radu (2012) find that the higher unemployment rate of return migrants one year after return disappears 
once the region of origin is taken into account. These findings suggest that returnees tend to gradually integrate with time, but this might be conditional on the performance of the specific labour market (i.e. regional or local) to which they return.

The literature also points to experiences or contexts that can complicate the process of return and hinder successful reintegration; this is often affected by labour market conditions in the home or host countries, as well as deteriorated or insufficient skills of returnees. Barcevičius et al. (2012) argue that returnees often encounter difficulties in reintegrating due to the gap in their career development. This is particularly the case for young people without previous work experience related to their qualifications, and for those who have worked in jobs unrelated to their formal qualifications.

Other studies find that the lack of suitable jobs in the home country labour market has constituted one of the major problems of reintegration (Schroth 2013). White (2014), analysing the return migration of Polish youth migrants from the UK and Ireland following the crisis, documents instances of failed return and 'double migration' back to the host country, due to the lack of employment opportunities in the regions of return. Analysing return migration to Romania and Bulgaria, Shima (2010) argues that labour market participation upon return is strongly determined by the fact of whether a given migrant intends to return permanently, and also by expectations about wage and skill premiums linked to work experience acquired abroad. Permanency of return intentions, however, is shaped by experiences abroad, family ties, and migration intentions of other family members. Her research - similarly to the approach in this paper - points to the interrelated nature of migration motivations, return motivations and labour market outcomes.

Return migration to Slovakia: what do we know?

Research about return migration to Slovakia is limited but growing. While it has been difficult to measure the magnitude of return migration, in recent years several studies have tried to estimate the numbers more precisely, relying on different data sources and measuring different types and forms of return migration. Rizman and Sacherová (2018) used administrative data, including information from health registry data; they found that in 2017, emigration and return migration dynamics equalized and stabilized at about 30 thousand return migrants annually. Their approach indicates that the authors have been able to map more permanent patterns of migration and return. Masso et al. (2018) used Labour Force Survey data to estimate the rate of return migration in Slovakia and Estonia. They found that in 2008 - 2016, about $10 \%$ of short-term work migrants returned to Slovakia, but this average rate of return was much lower than in Estonia. Bahna (2018) has focused specifically on the return migration 
of Slovak students from abroad, and estimated that in the horizon of more than two years since finishing studies abroad, about $40 \%$ of graduates decided to return to Slovakia. The analysis of online CVs presented in a study by $\mathrm{Ku}$ reková and Žilinčíková (2018) found that every fifth job seeker younger than 35 years of age had foreign work experience in his or her CV. Online surveys organized by the LEAF organization, about return intentions of Slovak migrants living abroad, found that about a half of migrants were undecided whether they would return to Slovakia, and more than a quarter had decided not to return (LEAF 2016). In 2018, return migration intentions were higher among respondents, regardless of the host country (LEAF 2018). In both surveys, migrants declared that the most important pull factor was an attractive job opportunity at home.

A set of studies analysed return migration before or around Slovakia's accession to the EU in 2004 (Williams - Baláž 2005; Williams - Baláž 2008), while more recent studies have focused on the aspects of return migration following the 2008-2009 economic crisis. Kureková and Žilinčíková (2018) studied online CVs, and found that returnees in Slovakia are attractive for employers because their migration experience signals a set of positive skills. On the other hand, returnees have higher wage expectations relative to stayers, which might complicate reintegration in lower-skilled occupations. The analysis of Slovak returnees' post-return labour market status shows that they are more likely to face short-term unemployment than are emigrants who remain abroad or people who have stayed at home (Masso et al. 2018).

Bahna (2018) studied factors affecting the return of Slovak university students from abroad, and found that while higher cultural capital of parents decreases chances of return, higher economic capital of the family increases the likelihood that the students will return in the two years following their graduation. Baláž et al. (2019) analysed competences and skills acquired in the process of international migration. They found that women and tertiary education returnees to Slovakia were able to gain relatively more competences while working abroad; higher self-confidence and ability to deal with challenges were valued the most. However, none of these studies has focused on potential diversity within the groups of return migrants, nor analysed how different motivations and expectations of the migration and return process might shape their reintegration prospects.

\section{Hypotheses}

Inspired by the reviewed literature about the determinants of return migration and post-return experiences, we employ the concept of successful versus failed return as an outcome variable. The success of return is operationalized by having a job (employed or self-employed) six months after returning, while failure 
is operationalized as being unemployed six months after returning. Our explicit goal is to study migration and return as an interrelated processes, which is less common in the current return migration scholarship (cf. Shima 2010). We therefore consider a set of socio-economic variables, economic factors, and motivational factors of migration and return, as explanatory variables.

First, we focus on the relationship between socio-demographic variables age, gender, marital status, and education - and success of return. We hypothesize that better-educated returnees will more successfully reintegrate into the home labour market, and include other aspects of personal characteristics as standard control variables.

Second, we collect and include in the analysis a set of variables for mapping economic and labour market factors. From the perspective of labour market experience from abroad, two factors are included: labour market status immediately prior to return, and whether a migrant was mismatched (overeducated) while working abroad. Poor labour market outcomes abroad might signal migration failure, but can also speed up their return decision. We hypothesize that being mismatched abroad can be poorly evaluated by employers in Slovakia or can lead to deskilling, thus making reintegration difficult. From the perspective of the home country, we consider whether returnees returned to the region of origin. We hypothesize that return to the region of origin can result in integration problems, because Slovak migrants are often from underperforming regions (Kahanec - Kureková 2016).

Third, through a set of questions inquiring about the main purpose of migration, key reasons for migration and reasons for return, we map issues related to preparedness, as well as achievement of goals set out in the initial migration plan. We expect successful returnees to be those who claimed that their return was influenced by having achieved their goals abroad.

\section{Data}

Data for return migration are scarce, and it is generally challenging to measure migration patterns in the context of free mobility in the European Union. This paper therefore relies on self-collected web survey data about returnees in Slovakia. Web surveys are a self-administered, fast and low-budget way of gathering data for quantitative analysis. The use of web-collected data to study return migration is not uncommon. To gather cross-country data, Lang et al. (2012) and Schroth (2013) organized web surveys, while Gherghina and Plopeanu (2020) conducted an online survey of return migrants in Romania, to collect (previously unavailable) data on emotional ties to the home country. Similarly, the studies about return migration in Slovakia by Bahna (2018) and Baláž et al. (2019) relied on web-collected data about return migrants and performed quantitative analysis. 
This analysis builds on web survey data collected from mid-October to early December 2015, using the surveymonkey.com platform. The target population was defined as any individuals who were employed abroad for at least three months, and the time elapsed from their return to Slovakia was at least 12 months (see the Appendix). The survey was supported by an active promotion campaign in social media and through personal networks. We also aimed to reach the unemployed, and therefore labour offices across Slovakia were approached with a request to promote the survey among their clients. The exact questions posed in the survey can be provided upon request.

The key motivation for gathering the data through a web survey was to collect information about those aspects of return which are not readily available in the representative datasets about the labour market, such as the LFS, which has been used to study migration and return in Slovakia (Kahanec - Kureková 2016, Masso et al. 2018). The survey helps us to map basic characteristics of returnees and further enrich the knowledge base about this group. We also include questions about motivations for both migration and return, and map different factors that could influence returnees' reintegration patterns into the labour market.

The formulation of questions was driven by theoretical expectations with respect to the role of economic and labour market factors, personal characteristics, and motivations for migration and return, which were supported by empirical findings from previous research on the topic. In addition, the survey entailed a set of questions investigating the role of institutions in facilitating the reintegration process after return (not analysed in this paper). Because our research was motivated by understanding the role of economic factors (macrolevel and individual) on return propensity and post-return experiences, we focused relatively less on the role of political factors, including political culture, quality of education and governance, corruption, or emotional reasons, which were covered in other return migration surveys organized in Slovakia (LEAF 2016; 2018).

Web-collected data clearly have some limitations and biases. First, data are based on individual self-assessment by the web survey respondents and cannot be verified. Second, the collected sample is unrepresentative, and tends to be biased towards individuals with higher digital exposure and better-educated people, which is the case also for our data. According to some studies, webbased surveys can nevertheless be used valuably to address certain questions about the labour market and to fill gaps in representative datasets (Kureková et al. 2015).

We collected a total of 217 fully completed responses. In the analysis of successful labour market reintegration of returnees, we only worked with those respondents who declared labour market participation (excluding students, 
retired and those on maternal/parental leave), resulting in the attrition of the analytical sample to 166 cases. The key characteristics of the analytical sample are summarized in Table 1. We also show a comparison sample of returnees identified in the Slovak Labour Force Survey (LFS), which is a representative dataset of the labour market. While LFS is not a migration or return migration dataset, we wanted to compare the structure of web survey data to a representative dataset of the overall population, in order to present the specific characteristics of return migrants captured in our analytical sample (Table 1, Table 2).

Table 1: Comparison of web survey sample and LFS sample of return migrants

\begin{tabular}{lccc}
\hline & \multicolumn{2}{c}{ Slovak Labour Force Survey } & \multicolumn{2}{c}{ Web survey } \\
\hline Female & Returnees & Total sample & Returnees \\
Mean age & 32.5 & 50.8 & 60.2 \\
Age 15-24 & - & - & 32.1 \\
$\mathbf{2 5 - 3 4}$ & 24.6 & 18.7 & 7.8 \\
35-44 & 37.4 & 18.7 & 59.6 \\
45+ & 17.3 & 18.9 & 29.5 \\
Low-educated (ISCED 0, 1, 2) & 20.7 & 43.6 & 3.0 \\
Middle-educated (ISCED 3, 4) & 4.3 & 16.5 & 0.6 \\
High-educated (ISCED 5, 6) & 90.3 & 69.6 & 26.5 \\
Total (N) & 5.5 & 13.9 & 72.9 \\
\hline
\end{tabular}

Source: Own calculations

Note 2: The SK-LFS sample includes all respondents interviewed between the years 2008 and 2013 in at least two waves of the survey. Returnees are defined as individuals working abroad at least in one wave before the last observation (in which they are observed in the home country). For methodology, see Masso et al. (2018).

The mean age of the web survey sample is 32 years, and - compared to the LFS data - returnees in the web sample are overwhelmingly concentrated in the $25-44$ age category. The sample we gathered is biased towards females $(60 \%)$ and, as expected, towards highly educated individuals. Almost three-quarters of the respondents have tertiary education, compared to only $6 \%$ of returnees in the LFS sample. Most of the respondents have worked in the UK, followed by Germany and the Czech Republic. In the LFS data, Hungary is a prominent return destination, which is not the case in the web survey data (Table 2). Due to data limitations, in terms of both the sample's composition and its relatively small size, our findings need to be interpreted with caution, and seen as an exploratory analysis, establishing a basis setting grounds for future research.

We have a twofold explanation for the educational and skill bias of the web survey sample. First, it could be an outcome of the advertising techniques we used for the survey, and the fact that the internet continues to be more accessi- 
ble to better-educated and younger individuals. The structure of the data, however, also resembles the selectivity of migrants in the first place, who tend to be younger and better educated relative to the general population. Second, the differences in the structure of returnees in the web survey data and LFS data could be due to specificities of the latter survey's data collection. LFS underestimates migrants and returnees because it gathers data at the level of households, and underestimates small and economically independent household units (Bahna 2013; Kahanec - Kureková 2016). Furthermore, LFS only captures short-term migrants (up to one year) and recent returnees, while the web survey captures returnees who worked abroad a longer time ago, or more permanently. Indeed, according to our data, about half of the web survey respondents had worked abroad for less than a year, a quarter between one and five years, and 13 per cent for more than five years (not displayed).

\section{Table 2: Top ten host countries}

\begin{tabular}{lllllll}
\hline & Web survey & N & Per cent & LFS - returnees & N & Per cent \\
\hline 1 & UK & 48 & 28.9 & CZ & 59 & 28.9 \\
2 & DE & 19 & 11.5 & UK & 43 & 21.1 \\
3 & CZ & 17 & 10.2 & HU & 19 & 9.3 \\
4 & US, CA & 12 & 7.2 & AT & 18 & 8.8 \\
5 & AT & 11 & 6.6 & IT & 14 & 6.9 \\
6 & FR & 8 & 4.8 & DE & 11 & 5.4 \\
7 & other EU & 10 & 6.0 & Other & 8 & 3.9 \\
8 & IE & 8 & 4.8 & NL & 6 & 2.9 \\
9 & European, non-EU & 8 & 4.8 & EU - unspecified & 6 & 2.9 \\
10 & BE & 7 & 4.2 & CH & 5 & 2.5 \\
\hline
\end{tabular}

Source: Own calculations, methodology as in Table 1.

\section{Empirical analysis}

Operationalizing the success and failure of return

We distinguish successful returnees from failed returnees by having a labour market position six months after returning, using the survey question "What was your position in the labour market six months after your return?" We define as successful returnees those respondents who had stated that they were employed (private or public sector, or self-employed), and as failed returnees those respondents who stated that they were unemployed six months after returning to Slovakia. Based on this definition, $19 \%$ of returnees are failed returnees. We effectively excluded from the larger original sample those respondents who stated that they were students, on maternity/parental leave, or retired. 
The half-year period for measuring employment status and evaluating the success of reintegration was inspired by several considerations. First, findings in a related study about the labour market outcomes of returnees found that returnees are up to ten times more likely to be unemployed three months after return, relative to migrants and stayers with similar characteristics (Masso et al. 2018). The aforementioned study interpreted its findings in light of the secured financial resources as well as the higher wage and job-match expectations of returnees, which led them to use a lengthier and more targeted job search strategy. On the other hand, we considered it unlikely that returnees would take more than six months to find a job, not least due to their high attractiveness in the labour market (Kureková - Žilinčíková 2018) and their career expectations (LEAF 2018). We therefore considered a six-month period - while certainly arbitrary - as the most suitable approach to study the success of return, compared to other options available in the data or typically included in different analyses (three months or one year).

\section{Descriptive statistics}

Table 3 presents the descriptive statistics for the total analytical sample, and separately for failed and successful returnees. We identify several differences in the socio-demographic characteristics between successful and failed returnees. Successful returnees are more likely to be married than failed returnees (34\% versus $13 \%)$, and they are significantly better educated (78\% with tertiary education, versus $50 \%$ ). Females represent a somewhat higher share among failed returnees $(66 \%)$ than among successful ones $(60 \%)$. The mean age in the two groups is similar (31-32 years).

With respect to economic and labour market factors, we do not see major differences between the two groups of returnees in their labour market status prior to returning to Slovakia. About four-fifths of both groups were employed, and about $15 \%$ in each group had been studying prior to returning. Only a relatively small share were unemployed: $3 \%$ among failed returnees and $7 \%$ among successful returnees. Greater differences exist in the extent of their return to the region of origin $-88 \%$ of failed returnees versus $81 \%$ of successful returnees returned to the region in Slovakia which they had left. A half of failed returnees were overeducated when working abroad, while this share was somewhat lower among successful returnees $(46 \%)$.

Regarding the motivation factors for migration and return, in both groups (finding) a job abroad was the primary purpose of migration (72\% of failed returnees and $75 \%$ of successful returnees). However, the purpose of studying was much more dominant among successful returnees, of whom $34 \%$ left to study abroad, compared to only $13 \%$ among failed returnees. 
Table 3: Descriptive statistics (in \%) $\mathbf{N = 1 6 6}$

\begin{tabular}{|c|c|c|c|c|}
\hline & & Failed returnees & Successful returnees & Total \\
\hline \multirow{6}{*}{$\begin{array}{l}\text { Socio-demographic } \\
\text { characteristics }\end{array}$} & age & 30.8 & 32.4 & 32.1 \\
\hline & female & 65.6 & 59.0 & 60.2 \\
\hline & married & 12.5 & 33.6 & 29.5 \\
\hline & education & & & \\
\hline & primary + secondary (ref) & 50 & 21.6 & 27.1 \\
\hline & tertiary & 50 & 78.4 & 72.9 \\
\hline \multirow[t]{8}{*}{ Economic factors } & Overeducated while abroad & & & \\
\hline & not over-educated & 50 & 54.5 & 53.6 \\
\hline & over-educated & 50 & 45.5 & 46.4 \\
\hline & LM status prior to return & & & \\
\hline & employed & 81.3 & 78.4 & 78.9 \\
\hline & unemployed + inactive & 3.1 & 6.7 & 6.0 \\
\hline & student & 15.6 & 14.9 & 15.1 \\
\hline & Return to the region of origin & 87.5 & 80.6 & 81.9 \\
\hline \multirow{25}{*}{$\begin{array}{l}\text { Motivational factors for } \\
\text { migration and return }\end{array}$} & Purpose of migration ${ }^{a}$ & & & \\
\hline & job & 71.9 & 75.4 & 74.7 \\
\hline & studies & 12.5 & 34.3 & 30.1 \\
\hline & partner & 12.5 & 9.0 & 9.6 \\
\hline & other & 12.5 & 7.5 & 8.4 \\
\hline & Key motivation for migration ${ }^{a}$ & & & \\
\hline & financial reasons & 46.9 & 30.6 & 33.7 \\
\hline & job search difficulties & 43.8 & 14.2 & 19.9 \\
\hline & low salary & 43.8 & 14.2 & 19.9 \\
\hline & profession mismatch & 25.0 & 12.7 & 15.1 \\
\hline & few opportunities for the young & 43.8 & 16.4 & 21.7 \\
\hline & political reasons & 12.5 & 6.7 & 7.8 \\
\hline & $\begin{array}{l}\text { better career opportunities } \\
\text { abroad }\end{array}$ & 25.0 & 41.0 & 38.0 \\
\hline & $\begin{array}{l}\text { better education opportunities } \\
\text { abroad }\end{array}$ & 28.1 & 35.1 & 33.7 \\
\hline & personal reasons & 21.9 & 20.2 & 20.5 \\
\hline & other & 6.3 & 11.9 & 10.8 \\
\hline & Country of migration & & & \\
\hline & $\mathrm{UK}+\mathrm{IE}$ & 34.4 & 33.6 & 33.7 \\
\hline & $\mathrm{CZ}$ & 3.1 & 11.9 & 10.2 \\
\hline & $\mathrm{DE}+\mathrm{AT}$ & 25.0 & 16.4 & 18.7 \\
\hline & other EU & 15.6 & 22.4 & 21.1 \\
\hline & non-EU & 21.9 & 15.7 & 16.9 \\
\hline & Reasons for return $^{a}$ & & & \\
\hline & joblessness abroad & 12.5 & 9.0 & 9.6 \\
\hline & worse living conditions abroad & 3.1 & 3.0 & 3.0 \\
\hline
\end{tabular}

Sociológia 52, 2020, No. 6 


\begin{tabular}{|c|c|c|c|c|}
\hline & & Failed returnees & Successful returnees & Total \\
\hline & career reasons & 12.5 & 11.9 & 12.1 \\
\hline & personal reasons & 59.4 & 56.7 & 57.2 \\
\hline & achievement of goals abroad & 15.6 & 41.8 & 36.8 \\
\hline & $\begin{array}{l}\text { better economic situation in } \\
\text { Slovakia }\end{array}$ & 6.3 & 6.7 & 6.6 \\
\hline & other & 6.3 & 11.9 & 10.8 \\
\hline \multirow{17}{*}{$\begin{array}{l}\text { Aspects of labour market } \\
\text { integration }\end{array}$} & Position after return & & & \\
\hline & high & 15.6 & 58.2 & 7.8 \\
\hline & middle & 18.8 & 28.4 & 26.5 \\
\hline & low & 15.6 & 6.0 & 50 \\
\hline & non-working & 50.0 & 7.5 & 15.7 \\
\hline & $\begin{array}{l}\text { Upgrade of position after } \\
\text { return }\end{array}$ & 15.6 & 39.6 & 34.9 \\
\hline & $\begin{array}{l}\text { Accepting first job offer after } \\
\text { return }\end{array}$ & & & \\
\hline & yes & 9.4 & 57.5 & 48.2 \\
\hline & no & 46.9 & 41.0 & 42.2 \\
\hline & non-working & 43.8 & 1.5 & 9.6 \\
\hline & Reason for rejection $^{\text {ab }}$ & & & \\
\hline & salary & 80.0 & 49.1 & 55.7 \\
\hline & location & 6.7 & 5.5 & 5.7 \\
\hline & outside field of study & 20.0 & 38.2 & 34.3 \\
\hline & other & 6.7 & 25.5 & 21.4 \\
\hline & Years since return & 2.1 & 4.6 & 4.2 \\
\hline & $\mathbf{N}$ & 32 & 134 & 166 \\
\hline
\end{tabular}

${ }^{a}$ The categories of the variable are not mutually exclusive

${ }^{\mathrm{b}}$ Reason for rejection applies only to those respondents who rejected the first job offer $(\mathrm{N}=70)$

We also map several differences in key motivations for migration. Failed returnees were to a much larger extent motivated to migrate by financial reasons $(47 \%$ versus $31 \%$ ), job search difficulties (44\% versus $14 \%$ ) and low salaries (44\% versus $14 \%$ ). Failed returnees also more often stated that they were motivated to seek work abroad due to profession mismatch at home $(25 \%$ versus $13 \%$ ) and fewer opportunities for young people (44\% versus $16 \%$ ). Furthermore, failed returnees seem to be less positive about prospects abroad: $25 \%$ of failed returnees versus $41 \%$ of successful ones believed that there were better career opportunities or better education opportunities abroad (28\% versus $35 \%$ ). On the other hand, we do not see many differences with respect to reasons for return between successful and failed returnees, with the exception being achievement of goals abroad: while only $16 \%$ of failed returnees stated this to be a reason for return, as much as $42 \%$ of successful returnees 
did so. The most popular destination among the returnees was the UK and Ireland, for both groups of returnees. Successful returnees had most often left the Czech Republic, while failed returnees most frequently returned from Germany, Austria or non-EU countries.

In Table 3 we also present aspects of labour market integration, which are not included in the logistic regression, but shed some light on the quality of labour market integration, and also on possible reasons for unemployment half a year after return. Failed returnees more commonly worked in low-skilled positions (16\% compared to $6 \%)$ and less often worked in high-skilled jobs, relative to successful returnees (16\% compared to $58 \%$ ). Furthermore, $40 \%$ of the successful returnees but only $16 \%$ of the failed returnees upgraded their position to a higher skill level compared to their position abroad. In addition, $42 \%$ of the respondents rejected the first job offer after returning, with only a slightly higher share of failed returnees $(47 \%)$ than successful returnees $(41 \%)$. The main reason for the rejection was low salary. This was a major reason for job rejection among the failed returnees $(80 \%)$, but also for the successful ones (49\%). Their position being outside the field of study, and 'other reasons', were also important for rejecting the job offer, especially among the successful returnees.

\section{Results}

We test the theoretical propositions in a set of probabilistic regressions which estimate the likelihood of a successful return, conditional on a set of different factors. Logistic regression is a widely used statistical technique employed for binary dependent variables, and it allows assessment of the relationship between an outcome variable and predictor variables in a multivariate way. Our key groups of variables of interest, for which we anticipate a significant association with successful return, are: individual (socio-demographic) characteristics; labour market factors; and motivational factors underlying decision to migrate and to return, including preparedness in terms of achievement of goals abroad.

We estimate the relationship between the independent and a dependent variable in five models. In the first model (M1) we enter only the individual (sociodemographic) characteristics; in the second model (M2) we add to M1 labour market factors. In the remaining three models (M3-M5) we add motivational variables in a stepwise manner to M2, in order to avoid over-specification of the model. To evaluate the statistical models, we report McFadden's pseudo Rsquared, to indicate which model better predicts the outcome; a likelihood ratio test, indicating whether the introduction of the new variables into the model improved the fit of the model; and the Hosmer-Lemeshow test, which indicates a model's goodness-of-fit. The statistics were estimated using the statistical 
software Stata 14. The results of the logistic regressions are presented in Table 4, and the goodness-of-fit statistics can be found in Table 5.

From a set of socio-demographic factors, we find that age, being a woman or being single/married have no effect on the odds of being a successful returnee. On the other hand, we find that education significantly affects success of return: having tertiary education increases the likelihood of success by about three times. However, this significance disappears in the model specification (M4) when factors motivating migration are included. This might imply that people with tertiary education are significantly different in their motivations for migration.

The analysis shows that labour market factors have no significant effect in terms of predicting the chances of smooth labour market integration after return. Labour market status prior to returning, being overeducated abroad, or returning to the region of origin do not explain successful return. Although the pseudo R-squared of M2 slightly increases in comparison to M1, the likelihood ratio test indicates that the labour market characteristics did not improve the fit of the model significantly.

We find several significant results among motivational factors. First, the main purpose of migration being linked to the desire to study abroad (rather than to family migration or other reasons) significantly increases the likelihood of a successful return. M3 shows that migration with the aim of studying abroad raises the chances of successful return by about six times. The value of pseudo R-squared increased from 0.098 in M2 to 0.149 in M3. The likelihood ratio test indicates that the inclusion of the purpose of migration did improve the fit of the model marginally significantly.

Second, M4 shows that those who migrated due to their dissatisfaction with wage levels in Slovakia are more than three times less likely to be a successful returnee. This again might allude to the fact that the speed of reintegration to the home labour market might be conditional on expectations linked to wages. The pseudo R2 indicates that this model predicts the outcome better than the rest of the models, and the likelihood ratio test shows that including the factors motivating migration improves the fit of the model significantly.

Third, in M5, we find that those migrants who returned after having achieved goals related to migration are about six times more likely to be successful returnees. Nevertheless, the goodness-of-fit statistics suggest that the inclusion of the factors motivating return do not significantly improve the fit of the model. Hosmer-Lemeshow tests indicate that all models M1-M5 fit the data well. In the next section we discuss the results in relation to theoretical expectations, as well as compared to previous empirical findings for Slovakia and other Central and Eastern European countries. 
Table 4: Determinants of successful return. Odds ratios from the logistic regressions

\begin{tabular}{|c|c|c|c|c|c|c|c|}
\hline & & & M1 & M2 & M3 & M4 & M5 \\
\hline & & & OR & OR & OR & OR & OR \\
\hline \multirow{7}{*}{$\begin{array}{l}\text { (1) Individual charac- } \\
\text { teristics }\end{array}$} & Age & & 0.997 & 0.996 & 1.000 & 0.994 & 1.000 \\
\hline & \multirow[t]{2}{*}{ Gender } & male (ref) & 1.000 & 1.000 & 1.000 & 1.000 & 1.000 \\
\hline & & female & 0.691 & 0.723 & 0.765 & 0.646 & 0.792 \\
\hline & \multirow[t]{2}{*}{ Marital status } & not married (ref) & 1.000 & 1.000 & 1.000 & 1.000 & 1.000 \\
\hline & & married & 2.968 & 2.855 & 2.937 & 2.704 & 2.915 \\
\hline & \multirow[t]{2}{*}{ Education } & primary + secondary (ref) & 1.000 & 1.000 & 1.000 & 1.000 & 1.000 \\
\hline & & tertiary & $3.049^{* *}$ & $3.313 * *$ & $2.848^{*}$ & 2.112 & $3.086^{*}$ \\
\hline \multirow[t]{6}{*}{$\begin{array}{l}\text { (2) Labour market } \\
\text { factors }\end{array}$} & $\begin{array}{l}\text { Return to the region } \\
\text { of origin }\end{array}$ & & & 0.787 & 0.725 & 0.954 & 0.838 \\
\hline & \multirow{3}{*}{$\begin{array}{l}\text { Labour market status } \\
\text { immediately prior to } \\
\text { return }\end{array}$} & employed (ref) & & 1.000 & 1.000 & 1.000 & 1.000 \\
\hline & & unemployed & & 2.732 & 2.503 & 3.049 & 3.380 \\
\hline & & student & & 0.821 & 0.542 & 0.565 & 0.881 \\
\hline & \multirow[t]{2}{*}{ Mismatched abroad } & not overeducated (ref) & & 1.000 & 1.000 & 1.000 & 1.000 \\
\hline & & overeducated & & 0.756 & 0.807 & 1.086 & 0.777 \\
\hline \multirow{8}{*}{$\begin{array}{l}\text { (3) Motivational fac- } \\
\text { tors }\end{array}$} & \multirow{4}{*}{$\begin{array}{l}\text { Main purpose of migra- } \\
\text { tion }\end{array}$} & job & & & 1.868 & & \\
\hline & & studies & & & $5.728^{*}$ & & \\
\hline & & partner & & & 1.151 & & \\
\hline & & other & & & 0.976 & & \\
\hline & \multirow{4}{*}{$\begin{array}{l}\text { Key motivations } \\
\text { for migration }\end{array}$} & financial reasons & & & & 0.902 & \\
\hline & & job search difficulties & & & & 0.359 & \\
\hline & & low salary & & & & $0.310^{*}$ & \\
\hline & & profession mismatch & & & & 0.849 & \\
\hline
\end{tabular}




\begin{tabular}{|c|c|c|c|c|c|c|}
\hline & & M1 & M2 & M3 & M4 & M5 \\
\hline & & OR & OR & OR & OR & OR \\
\hline \multirow{13}{*}{ Reasons for return } & few opportunities for the young & & & & 0.433 & \\
\hline & political reasons & & & & 0.885 & \\
\hline & better career opportunities abroad & & & & 1.713 & \\
\hline & $\begin{array}{l}\text { better education opportunities } \\
\text { abroad }\end{array}$ & & & & 1.268 & \\
\hline & personal reasons & & & & 1.243 & \\
\hline & other & & & & 1.444 & \\
\hline & joblessness abroad & & & & & 1.789 \\
\hline & worsened living conditions abroad & & & & & 3.906 \\
\hline & career reasons & & & & & 2.399 \\
\hline & personal reasons & & & & & 2.555 \\
\hline & achievement of goals abroad & & & & & $5.605^{*}$ \\
\hline & $\begin{array}{l}\text { better economic situation in Slova- } \\
\text { kia }\end{array}$ & & & & & 1.740 \\
\hline & other & & & & & 4.080 \\
\hline $\mathbf{N}$ & & 166 & 166 & 166 & 166 & 166 \\
\hline
\end{tabular}

Note: Logistic regression, odds ratios. Significance: ${ }^{*} \mathrm{p}<.05 . * * \mathrm{p}<.01 . * * * \mathrm{p}<.001$ 
Table 5: Goodness-of-fit statistics of logistic regression models

\begin{tabular}{llll|lcc}
\hline Model & $\begin{array}{l}\text { McFadden's } \\
\text { pseudo R2 }\end{array}$ & $\begin{array}{l}\text { Hosmer- } \\
\text { Lemeshow chi2 }\end{array}$ & P-value $^{\text {a }}$ & $\begin{array}{l}\text { Contrast } \\
\text { models }\end{array}$ & $\begin{array}{c}\text { between Likelihood } \\
\text { ratio chi2 }\end{array}$ & P-value $^{\text {b }}$ \\
\hline M1 & 0.086 & 9.47 & 0.3039 & & & \\
M2 & 0.098 & 10.62 & 0.2239 & M2-M1 & 1.86 & 0.7622 \\
M3 & 0.149 & 2.36 & 0.9680 & M3-M2 & 8.35 & 0.0795 \\
M4 & 0.226 & 10.16 & 0.2538 & M4-M2 & 20.85 & 0.0221 \\
M5 & 0.157 & 11.82 & 0.1592 & M5-M2 & 9.70 & 0.2061 \\
\hline
\end{tabular}

a - a significant p-value indicates that the model does not fit the data well.

${ }^{b}$ - a significant $\mathrm{p}$-value indicates that by adding variables a fit of the model was improved.

\section{Discussion of findings}

With respect to the theoretical expectations and hypotheses formulated on the basis of previous research, our results are mixed. First, regarding the role of personal characteristics, we confirm that the level of education plays a role in the success or failure of return, but do not find evidence for other individual characteristics, such as age, gender or marital status. This is in line with those studies which document that better-educated returnees are less likely to be unemployed (Martin - Radu 2012), but contrary to those results which also document gender or age as aspects of a successful labour market reintegration (Co et al. 2000).

Second, we find no evidence for the hypotheses stated regarding the role of labour market factors. While we hypothesized that being mismatched abroad can be poorly evaluated by employers in Slovakia or can lead to deskilling, thus making reintegration troublesome, in fact the results for being overeducated abroad are insignificant across different model specifications. Hence, while a mismatch abroad might affect the decision to return, as documented for Poland (Curie 2007) or for Estonia (Pungas et al. 2012; Masso et al. 2018), it does not seem to be a significant factor explaining success of reintegration. This finding might be specific to Slovakia, which has suffered from severe skill shortages. It might also indicate that "Western" work experience has a universal value because it demonstrates and signals to employers a set of skills that they highly value (cf. Baláž et al. 2019; Kureková - Žilinčíková 2018). We also hypothesized that return to the region of origin can result in integration problems because Slovak migrants are often selected from underperforming regions, but empirical evidence does not confirm this hypothesis. Finally, labour market status prior to returning also plays no role in accounting for the failure or success of post-return labour market integration. This shows that while individual-level economic factors might prevail in motivations for emigration from 
Slovakia (Haluš et al. 2017; Kahanec - Kureková 2016), they appear less significant in explaining reintegration outcomes after returning from abroad.

Third, we find support for our hypothesis that successful returnees are those who claimed that their return was influenced by having achieved their goals abroad: migrants who returned after having fulfilled goals defined at the outset of the migration process had significantly higher chances of reintegrating successfully. Furthermore, those migrants who decided to work abroad due to low salaries in Slovakia had higher odds of facing difficulties in reintegrating into the labour market after return. This is in line with the findings of other studies which document that higher wage expectations of returnees might lead to difficulties in accepting positions after return; this was found specifically for Slovakia (Kureková - Žilinčíková 2018), but also in Estonia (Masso et al. 2014). On a descriptive level (Table 3), three-quarters of failed returnees said that their main reason for the job rejection was low salary.

In sum, it appears that migration strategies, and the preparedness of returnees - in the sense of having achieved migration plans - affect reintegration prospects more than the purely economic factors, such as the performance of the region of origin, over-qualification while working abroad, or labour market status prior to returning. This is, to the best of our knowledge, a novel finding that warrants further investigation.

However, we would like to highlight that our findings need to be interpreted with caution, and with consideration of the specific limitations and biases of our data. First, the analytical sample size is relatively small, which might lead to the under-reporting of possibly significant factors. Secondly, due to overrepresentation of highly educated returnees, our results cannot be considered robust with respect to other types of returnees. Third, our analysis in effect captures a particular point in time, and could in the future be verified with additional data collection; either in the form of a new web survey targeting returnees, or by qualitative research in the form of interviews with return migrants.

\section{Conclusion}

This paper contributes to the literature focusing on return migration, and broadens our knowledge about the main aspects of labour market reintegration for returnees in Slovakia. We believe that our exploratory study establishes a basis for further data collection and research to enhance our understanding of the interrelated nature of migration motivations, return motivations and post-return labour market outcomes.

From an academic perspective, our work adds to literature which has focused on understanding migrants' decisions from the perspective of their capabilities, aptitudes, aspirations and attitudes; these factors in effect mediate the interpretation of what might be objective economic differences between the 
home and host countries, and shape actual migration decisions (Carling Schewel 2018; Czaika - Vothknecht 2014). We believe there is scope to further theorize return migrants' decisions in the context of their perceptions and personal attitudes. From a policy perspective, our work implies that return migrants are in essence a heterogeneous group with different initial motivations for migration and reasons for return; these might be reflected in their decisions about labour market reintegration after return. Thus, it would be valuable to investigate how home country institutions and policies, such as labour offices or unemployment benefit schemes, might be harnessed to support successful rather than failed labour market reintegration.

Finally, the recent Coronavirus crisis raises additional questions with respect to returnees' labour market trajectories. Much return migration in response to the Covid pandemic was in the context of "unfinished" migration plans, and often resulted in an abrupt return. Possible future research could focus on understanding the impact of Covid-contextualized return migration under the conditions of falling labour markets across Europe, as well as general limitations on mobility in several European countries.

Lucia Mýtna Kureková works as a senior researcher at the Centre for Social and Psychological Sciences of the Slovak Academy of Sciences, Institute for Forecasting. She gained her PhD in political science and political economy in 2011, from the Central European University in Budapest. Her research focuses on labour migration and migrant integration; skill formation and education systems; innovative data sources; and industrial, economic and social policy. Lucia has widely published in these fields, and gained research and research management experience in various international research projects, including POW-BRIDGE, STYLE, NEUJOBS, SEEMIG and ENPI. She has worked as a consultant and national expert for international organizations, including the World Bank, CEDEFOP and OECD, on topics related to skills governance, $V E T$, career guidance, and social inclusion. She has been a member of the EENEE network since 2020, and an editorial board member of the Journal of Economics (Ekonomický časopis) since 2019. She is also affiliated with the Slovak Governance Institute (SGI), Central European Labour Studies Institute (CELSI), Global Labour Organization (GLO) and Institute for the Study of Labour in Bonn (IZA).

Zuzana Žilinčíková is a postdoctoral researcher at the Centre for Demographic Research (DEMO) at UCLouvain. She received her doctoral degree in sociology at Masaryk University in 2019. In her research, she focuses on family dynamics (mainly partnership formation and dissolution, and intergenerational ties) and migration. Zuzana has published in journals such as the Jour- 
nal of Family Issues, Population, Advances in Life Course Research, Comparative Population Studies, and the International Journal of Manpower.

\section{REFERENCES}

AMBROSINI, J. W. - MAYR, K. - PERI, G. - RADU, D., 2011: The Selection of Migrants and Returnees: Evidence from Romania and Implications. Working Paper 16912. National Bureau of Economic Research.

BAHNA, M., 2013: Intra-EU Migration from Slovakia: An Evaluation of New Economics of Labour Migration and Migrant Networks Theories. European Societies 15(3): 388-407. https://doi.org/10.1080/14616696.2012.707669

BAHNA, M., 2018: Study Choices and Returns of International Students: On the Role of Cultural and Economic Capital of the Family. Population, Space and Place 2(24) e2082. https://doi.org/10.1002/psp.2082

BALÁŽ, V. - WILLIAMS, A. M. - MORAVČÍKOVÁ, K. - CHRANČOKOVÁ, M., 2019: What Competences, which Migrants? Tacit and Explicit Knowledge Acquired Via Migration. Journal of Ethnic and Migration Studies 0(0): 1-17. https://doi.org/10.1080/1369183X.2019.1679409

BARCEVIČIUS, E. - IGLICKA, K. - REPEČKAITĖ, D. - ŽVALIONYTĖ, D., 2012: Labour Mobility within the EU: The Impact of Return Migration. EUROFOUND.

CARLING, J. - SCHEWEL, K., 2018: Revisiting Aspiration and Ability in International Migration. Journal of Ethnic and Migration Studies 6(44): 945-963. https://doi.org/10.1080/1369183X.2017.1384146

CASSARINO, J.-P., 2004: Theorising Return Migration: The Conceptual Approach to Return Migrants Revisited. International Journal on Multicultural Societies 2(6): 253-279.

CO, C. - GANG, I. N. - YUN, M.-S., 2000: Returns to Returning.Journal of Population Economics 1(13): 57-79. https://doi.org/10.1007/s001480050123

CREŢAN, R. - LIGHT, D., 2020: COVID-19 in Romania: Transnational Labour, Geopolitics, and the Roma 'Outsiders'. Eurasian Geography and Economics, pp. 1-14. https://doi.org/10.1080/15387216.2020.1780929

CURRIE, S., 2007: De-Skilled and Devalued: The Labour Market Experience of Polish Migrants in the UK Following EU Enlargement. International Journal of Comparative Labour Law and Industrial Relations 1(23): 83-116.

CZAIKA, M. - VOTHKNECHT, M., 2014: Migration and Aspirations-Are Migrants Trapped on a Hedonic Treadmill? IZA Journal of migration 1(3): 1. https://doi.org/10.1186/2193-9039-3-1

DE HAAS, H. - FOKKEMA, T. - FIHRI, M. F., 2015: Return Migration as Failure or Success? Journal of International Migration and Integration 2(16): 415-429. https://doi.org/10.1007/s12134-014-0344-6

DRINKWATER, S. - EADE, J. - GARAPICH, M., 2009: Poles Apart? EU Enlargement and the Labour Market Outcomes of Immigrants in the United Kingdom. International Migration 1(47): 161-190. https://doi.org/10.1111/j.1468-2435.2008. 00500.x

DUMONT, J.-C. - SPIELVOGEL, G., 2008: Return Migration: A New Perspective. International Migration Outlook, Annual Report. SOPEMI. OECD. 
DUSTMANN, C., 2003: Return Migration, Wage Differentials, and the Optimal Migration Duration. European Economic Review 2(47): 353-369. https://doi.org/10.1016/S0014-2921(01)00184-2

GALGÓCZI, B. - LESCHKE, J. - WATT, A., 2012: Eu Labour Migration in Troubled Times: Skills Mismatch, Return and Policy Responses. Ashgate Publishing.

GALGÓCZI, B. - LESCHKE, J. - WATT, M. A., 2013: EU Labour Migration Since Enlargement: Trends, Impacts and Policies. Ashgate Publishing, Ltd.

GHERGHINA, S. - PLOPEANU, A. P., 2020: Who Wishes to Return? Ties to Home Country Among the Romanian Migrants. Ties to Home Country Among the Romanian Migrants. https://doi.org/10.2139/ssrn.3578815

HALUŠ, M. - HLAVÁČ, M. - HAVRAN, P. - HIDAS, S., 2017: Odliv mozgov po slovensky. Inštitútu finančnej politiky. Komentár 2017/1.

HAZANS, M. - PHILIPS, K., 2010: The Post-Enlargement Migration Experience in the Baltic Labor Markets. In: Kahanec, M., Zimmermann, K. F. (eds.): EU Labor Markets after Post-Enlargement Migration. Springer, Berlin - Heidelberg, pp. 255304. https://doi.org/10.1007/978-3-642-02242-5_10

HOLLAND, D. - FIC, T. - RINCON-AZNAR, A. - STOKES, L. - PALUCHOWSKI, P., 2011: Labour Mobility within the EU-The Impact of Enlargement and the Functioning of the Transitional Arrangements. National Institute of Economic and Social Research, 2978.

IARA, A., 2006: Skill Diffusion in Temporary Migration? Returns to Western European Working Experience in the EU Accession Countries. Returns to Western European Working Experience in the EU Accession Countries (March 2006). Centro Studi Luca d'Agliano Development Studies Working Paper, No. 210. https://doi.org/10.2139/ssrn.918037

JANICKA, A. - KACZMARCZYK, P., 2016: Mobilities in the Crisis and Post-Crisis Times: Migration Strategies of Poles on the EU Labour Market. Journal of Ethnic and Migration Studies 42(10): 1693-1710. https://doi.org/10.1080/1369183X.2016.1162350

KAHANEC, M. - FABO, B., 2013. Migration Strategies of Crisis-Stricken Youth in an Enlarged European Union. Transfer: European Review of Labour and Research 19(3): 365-380. https://doi.org/10.1177/1024258913493701

KAHANEC, M. - KUREKOVÁ, L. M., 2016: Did Post-Enlargement Labor Mobility Help the EU to Adjust During the Great Recession? The Case of Slovakia. In: Kahanec, M., Zimmermann, K. F. (eds.): Labor Migration, EU Enlargement, and the Great Recession. Springer, Berlin. https://doi.org/10.1007/978-3-662-45320-9

KAHANEC, M. - PYTLIKOVÁ, M., 2017: The Economic Impact of East-West Migration on the European Union. Empirica 3(44): 407-434. https://doi.org/10.1007/s10663-017-9370-X

KAHANEC, M. - ZIMMERMANN, K. F., 2010: EU Labor Markets after PostEnlargement Migration. Springer, Berlin, Germany. https://doi.org/10.1007/978-3-642-02242-5

KAHANEC, M. - ZIMMERMANN, K. F., 2016: Labor Migration, EU Enlargement, and the Great Recession. Springer, Berlin. https://doi.org/10.1007/978-3-66245320-9 
KUREKOVÁ, L. M. - BEBLAVÝ, M. - THUM-THYSEN, A., 2015: Using Online Vacancies and Web Surveys to Analyse the Labour Market: a Methodological Inquiry. IZA Journal of Labor Economics 1(4): 18. https://doi.org/10.1186/s40172-015-0034-4

KUREKOVÁ, L. M. - ŽILINČÍKOVÁ, Z., 2018: What is the Value of Foreign Work Experience for Young Return Migrants? International Journal of Manpower 39(1). https://doi.org/10.1108/IJM-04-2016-0091

LANG, T. - HÄMMERLING, A. - KEIL, J. - NADLER, R. - SCHMIDT, A. HAUNSTEIN, S. - SMOLINER, S., 2012: Re-Turn Migrant Survey Report: The Migrants' Potential and Expectations. Leibniz Institute for Regional Geography (IfL).

LEAF, 2016: Prieskum medzi Slovákmi v zahraničí. URL: https://spap.leaf.sk/prieskum2016/ (stiahnuté: 21.10.2020).

LEAF, 2018: Prieskum medzi Slovákmi v zahraničí. URL: https://spap.leaf.sk/prieskum (stiahnuté: 21.10.2020).

LINDSTROM, D. P., 1996: Economic Opportunity in Mexico and Return Migration from the United States. Demography 3(33): 357-374. https://doi.org/10.2307/2061767

MARTIN, R. - RADU, D., 2012: Return Migration: The Experience of Eastern Europe1. International Migration 6(50): 109-128. https://doi.org/10.1111/j.1468-2435.2012.00762.x

MASSO, J. - EAMETS, R. - MÕTSMEES, P., 2014: Temporary Migrants and Occupational Mobility: Evidence from the Case of Estonia. International Journal of Manpower 6(35): 753-775. https://doi.org/10.1108/IJM-06-2013-0138

MASSO, J. - KUREKOVÁ, L. M. - TVERDOSTUP, M. - ŽILINČÍKOVÁ, Z., 2018: What are the Employment Prospects for Young Estonian and Slovak Return Migrants? In: Youth Labor in Transition: Inequalities, Mobility, and Policies in Europe. New York: Oxford University Press, pp. 461-502. https://doi.org/10.1093/oso/9780190864798.003.0016

PUNGAS, E. - TOOMET, O. - TAMMARU, T. - ANNISTE, K., 2012: Are Better Educated Migrants Returning? Evidence from Multi-Dimensional Education Data. Norface Research Programme on Migration, Department of Economics, University College London.

RIZMAN, T. - SACHEROVÁ, K., 2018. Host' do domu. Analýza príchodov a odchodov obyvatel'stva na Slovensko. Inštitút finančnej politiky, Komentár 2018/6.

ROOTH, D.-O. - SAARELA, J., 2007: Selection in Migration and Return Migration: Evidence from Micro Data. Economics letters 1(94): 90-95. https://doi.org/10.1016/j.econlet.2006.08.006

ŠANTIĆ, D. - ANTIĆ, M., 2020: Serbia in the Time of COVID-19: Between "Corona Diplomacy", tough Measures and Migration Management. Eurasian Geography and Economics. Online first. pp. 1-13. https://doi.org/10.1080/15387216.2020.1780457

SCHROTH, J., 2013: International Comparative Working Paper "Barriers for Successful Capitalization on Returning Migrants”. IOM, Prague Office. 
SHIMA, I., 2010: Return Migration and Labour Market Outcomes of the Returnees. Does the Return Really Pay Off? The Case-Study of Romania and Bulgaria. In: FIW Research Reports 2009 10(7).

SMOLINER, S. - FÖRSCHNER, M. - HOCHGERNER, J. - NOVÁ, J., 2012: Comparative Report on Re-Migration Trends in Central Europe. Re-Turn, Centre for Social Innovation, Vienna, 81.

VLASE, I., 2013. My Husband is a Patriot!: Gender and Romanian Family Return Migration from Italy. Journal of Ethnic and Migration Studies 39(5): pp.741-758. https://doi.org/10.1080/1369183X.2013.756661

VOITCHOVSKY, S., 2014: Occupational Downgrading and Wages of New Member States Immigrants to Ireland. International Migration Review 48(2): 500-537. https://doi.org/10.1111/imre.12089

WHITE, A., 2014: Polish Return and Double Return Migration. Europe-Asia Studies 1(66): 25-49. https://doi.org/10.1080/09668136.2013.855021

WILliAMS, A. M. - BALÁŽ, V., 2005: What Human Capital, Which Migrants? Returned Skilled Migration to Slovakia From the UK. International Migration Review 2(39): 439-468. https://doi.org/10.1111/j.1747-7379.2005.tb00273.x

WILLIAMS, A. M. - BALÁŽ, V., 2008. International Return Mobility, Learning and Knowledge Transfer: A Case Study of Slovak Doctors. Social Science \& Medicine 67(11): 1924-1933. https://doi.org/10.1016/j.socscimed.2008.09.003

ZAICEVA, A. - ZIMMERMANN, K. F., 2016: Returning Home at Times of Trouble? Return Migration of EU Enlargement Migrants during the Crisis. In: Kahanec, M., Zimmermann, K. F. (eds.): Labor Migration, EU Enlargement, and the Great Recession. Springer Verlag, Berlin. https://doi.org/10.1007/978-3-662-45320-9_16

\section{Appendix}

Text of the advertisement preceding specific survey questions (in Slovak)

Milí respondenti,

d'akujeme za Váš záujem o účast' na prieskume.

Náš prieskum je zameraný na l'udí, ktorí istý čas pracovali v zahraničí a vrátili sa na Slovensko. Prieskum je súčast'ou výskumu v projekte STYLE, ktorý na Slovensku zastrešuje Inštitút pre dobre spravovanú spoločnost' - SGI. Vyplnenie dotazníka trvá približne 10 minút. Prosím vyplňte dotazník iba v prípade, že ste niekedy v minulosti pracovali v zahraničí (vrátane platenej stáže), Váš pobyt v zahraničí trval aspoň 3 mesiace a zároveň od Vášho príchodu na Slovensko uplynul aspoň rok. Po vyplnení dotazníka budete $\mathrm{v}$ prípade Vášho záujmu zaradený do zlosovania o tri poukážky na nákup v kníhkupectve Martinus, každá v hodnote $100 €$. Zlosovanie prebehne 1.12.2015, a zaradené budú všetky dotazníky plne vyplnené do tohto dátumu.

Ďakujeme 